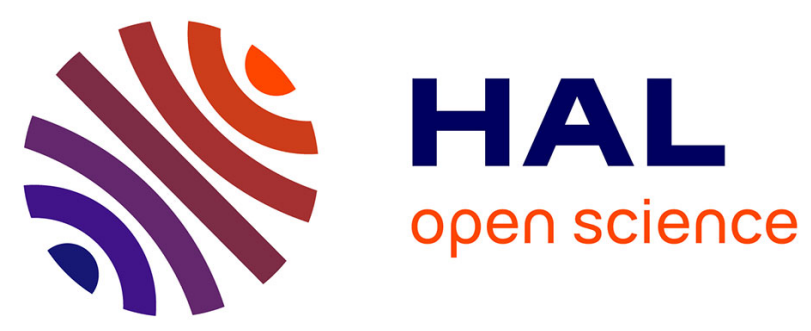

\title{
Cylindrospermopsin accumulation and release by the benthic cyanobacterium Oscillatoria sp. PCC 6506 under different light conditions and growth phases.
} Myriam Bormans, Marion Lengronne, Luc Brient, Charlotte Duval

\section{- To cite this version:}

Myriam Bormans, Marion Lengronne, Luc Brient, Charlotte Duval. Cylindrospermopsin accumulation and release by the benthic cyanobacterium Oscillatoria sp. PCC 6506 under different light conditions and growth phases.. Bulletin of Environmental Contamination and Toxicology, 2014, 92 (2), pp.243247. 10.1007/s00128-013-1144-y . hal-00957621

HAL Id: hal-00957621

https://hal-univ-rennes1.archives-ouvertes.fr/hal-00957621

Submitted on 20 Mar 2014

HAL is a multi-disciplinary open access archive for the deposit and dissemination of scientific research documents, whether they are published or not. The documents may come from teaching and research institutions in France or abroad, or from public or private research centers.
L'archive ouverte pluridisciplinaire HAL, est destinée au dépôt et à la diffusion de documents scientifiques de niveau recherche, publiés ou non, émanant des établissements d'enseignement et de recherche français ou étrangers, des laboratoires publics ou privés. 
Cylindrospermopsin accumulation and release by the benthic cyanobacterium

Oscillatoria sp PCC 6506 under different light conditions and growth phases

Bormans Myriam $^{1 *}$, Lengronne Marion ${ }^{1}$, Brient Luc ${ }^{1}$, Duval Charlotte ${ }^{2}$

${ }^{1}$ UMR 6553 ECOBIO, CNRS Université de Rennes 1, 35042 Rennes, France

${ }^{2}$ UMR 7245 CNRS Museum National d'Histoire Naturelle, 75005 Paris, France

*corresponding author : myriam.bormans@ univ-rennes1.fr, phone : +33 (0)2 23235979

\begin{abstract}
We have studied the dynamics of cylindrospermopsin concentration [CYN] of a benthic cyanobacterium of the genus Oscillatoria under various light conditions over the different growth phases. The present study is the first one reporting on the effect of abiotic factors on the CYN accumulation and release by a benthic species. In particular we have measured the concentrations of both intracellular and extracellular [CYN]. We found that the total CYN content is highest during the exponential growth phase at intermediate light level $\left(10 \mu \mathrm{E} \mathrm{m} \mathrm{m}^{-2} \mathrm{~s}^{-}\right.$ ${ }^{1}$ ) and during the stationary growth phase at more extreme lower and higher light levels. Our results also indicate that the amount of the extracellular form varied between 56 and $96 \%$ of the total CYN concentrations. We found no relationship between CYN content and growth rates. These results suggest many similarities with planktonic species but also highlight some differences.
\end{abstract}

\title{
KEYWORDS
}

Benthic cyanobacteria; cylindrospermopsin content; intracellular; extracellular; light intensity; growth phase

\section{INTRODUCTION}

Cyanobacteria are known to produce a variety of toxins, which have adverse effects on animals and humans (Codd et al. 2005). These toxins include microcystins, cylindrospermopsins, saxitoxins, nodularins, anatoxins and more recently beta-methylaminoL-alinine or BMAA. Although microcystin is the only toxin routinely monitored for health risks, there are an increasing number of studies reporting on the presence of all types of toxins in waterbodies. In particular, cylindrospermopsin (CYN) is rapidly being recognised as one of the globally problematic freshwater toxin due to its ever expanding distribution from tropical to temperate zones (Rücker et al. 2007 ; Brient et al. 2008 ; Sinha et al. 2012) and its ability to bioaccumulate in freshwater organisms (Kinnear 2010).

CYN is a tricyclic alkaloid cytotoxin produced by several cyanobacterial species: Cylindrospermopsis raciborskii, Aphanizomenon ovalisporum, Aphanizomenon flos aquae, Anabaena bergii, Anabaena lapponica, Umezakia natans, Raphidiopsis curvata and other unidentified species. Recently, several oscillatoriales have been identified as producing CYN as Lyngbya wollei (Seifert et al. 2007) and Oscillatoria sp. (Mazmouz et al. 2010). CYN is highly water soluble and is primary present in extracellular form (Chiswell et al. 1999; Rücker et al. 2007). CYN degrades relatively slowly by photodegradation (Wörmer et al. 2010) and biodegradation (Wörmer et al. 2008) explaining relatively high extracellular concentrations in the water.

In the field, Wiedner et al. (2008) found that CYN was essentially produced as extracellular form during the decline of a bloom. Some laboratory experiments on Cylindrospermopsis raciborskii (Saker and Griffith 2000; Hawkins et al. 2001; Dyble et al. 2006) confirm this 
tendency by demonstrating an increased accumulation of extracellular CYN during the stationary growth phase.

Abiotic factors that influence the accumulation and release of CYN have been studied both in the field and in laboratory experiments. The effect of temperature has been studied showing globally that an increase in temperature results in a decrease of CYN accumulation (Saker and Griffith 2000; Preußel et al. 2009; Cires et al. 2011). Nutrient concentrations also play a role in CYN accumulation. In studies with Aphanizomenon ovalisporum, an increase of CYN accumulation with limiting phosphorus conditions was shown (Bar Yosef et al. 2010) while higher CYN accumulation in cells grown in a culture medium with lower phosphorus concentration was also observed by Cires et al. (2011). Higher intracellular CYN concentration was also observed in controlled laboratory experiments with several strains of Cylindrospermopsis raciborskii in lower nitrogen medium (Saker and Neilan 2001). Light intensity has also been examined as a factor influencing CYN accumulation. Dyble et al. (2006) indicated an increase of total CYN concentration with an increase in light intensity between 18 and $75 \mu \mathrm{E} \mathrm{m}^{-2} \mathrm{~s}^{-1}$ for the species Cylindrospermopsis raciborskii at $25^{\circ} \mathrm{C}$. Similarly Cires et al. (2011) observed a significant increase of intracellular CYN between 15 and $60 \mu \mathrm{E} \mathrm{m}^{-2} \mathrm{~s}^{-1}$ on the species Aphanizomenon ovalisporum at $28^{\circ} \mathrm{C}$. However, according to Preußel et al. (2009), the impact of light intensity is temperature dependent, it increased at $20^{\circ} \mathrm{C}$ and decreased at $25^{\circ} \mathrm{C}$ for Aphanizomenon flos aquae for light ranging between 10 and $60 \mu \mathrm{E} \mathrm{m}^{-2} \mathrm{~s}^{-1}$.

To our knowledge, all of the studies reported in the literature on the role of abiotic factors in CYN accumulation have involved planktonic species. As CYN concentration has recently been measured on benthic species, we examined how abiotic factors affect CYN accumulation and release by a benthic species. In particular, this study examines the role of light intensity and growth phase on both intracellular and extracellular CYN concentrations by the benthic Oscillatoria sp. PCC 6506 recently identified as producing CYN (Mazmouz et al. 2010) under unlimited nutrient conditions. We hypothesize that CYN content will vary as a function of stressed conditions, therefore we expect differences between growth phases and between light levels.

\section{MATERIALS AND METHODS}

\section{Strain and cultures conditions}

The strain PCC 6506 is a filamentous species with slightly flexed trichomes. The CYN producing strain Oscillatoria sp. PCC 6506 was provided by the Pasteur Culture Collection of Cyanobacteria (Pasteur Institute in Paris) as an axenic culture which was grown in a BG11 medium at $20^{\circ} \mathrm{C}$ in a $14 \mathrm{~h} / 10 \mathrm{~h}$ light dark cycle. Three light intensities were tested $(2,10$ and $20 \mu \mathrm{E} \mathrm{m}^{-2} \mathrm{~s}^{-1}$ ) after a preliminary experiment identified that the culture was not growing at higher light intensity. Prior to the experiment each culture was pre-adapted for three weeks to its appropriate light intensity. All experiments were performed in triplicate batch cultures. An initial biomass of $10^{5}$ cells $\mathrm{mL}^{-1}$ was used in each culture. Toxin concentrations were measured at the same time (day 2, day 23 and day 51) for all three light levels.

\section{Biomass and growth kinetics}

Oscillatoria $s p$ cell density was estimated by converting the OD at $750 \mathrm{~nm}$ into cell density (cells $\mathrm{mL}^{-1}$ ) based on a linear relationship between these two parameters. The specific growth rates, $\mu\left(\right.$ day $\left.^{-1}\right)$, were calculated during the exponential growth phase according to the following equation:

$$
\mu=\left(\ln \mathrm{C}_{\mathrm{t}+\Delta \mathrm{t}}-\ln \mathrm{C}_{\mathrm{t}}\right) /(\Delta \mathrm{t})
$$


where $C_{t}$ and $C_{t+\Delta t}$ represent the cell density (cells $\mathrm{mL}^{-1}$ ) at times $t$ and $t+\Delta t$, respectively.

Cell counts were obtained with a Nageotte cell on an optical microscope counting a minimum of 2000 cells. Optical density was measured twice a week to follow the evolution of the biomass, identify growth phases and calculate growth rates. The toxin concentration was tested prior to the experiment to determine appropriate volumes to sample. Samples of $1 \mathrm{~mL}$ were collected in each replicate during the different phases (latent, exponential and stationary) and analysed for intracellular and extracellular CYN concentrations.

\section{Toxin analyses}

Separation of intracellular and extracellular CYN was achieved by low vacuum filtration on a $\mathrm{GF} / \mathrm{F}$ filter. The filtrate was stored at $-18^{\circ} \mathrm{C}$ for extracellular analysis. For the intracellular form, the biomass recovered on the filter was dried for $3 \mathrm{~h}$ at $35^{\circ} \mathrm{C}$ and resuspended in $5 \mathrm{~mL}$ of ultrapure water before being stored with the filter at $-18^{\circ} \mathrm{C}$. After thawing, extractions were performed according to Welker et al. (2002) and adapted for the specification of strain PCC 6506 as of Mazmouz et al. (2010). Samples (biomass and filter) were subjected to ultrasounds using a Sonics Vibracell probe for $60 \mathrm{~s}$ at $130 \mathrm{~W}$ then placed on an orbital shaker at $300 \mathrm{rpm}$ for $1 \mathrm{~h}$ at room temperature. They were again subjected to 60 s of ultrasounds and filtered on $0.45 \mu \mathrm{m}$ nylon filter.

Concentrations were measured using a Cylindrospermopsin ELISA kit from Abraxis and analysed with a spectrophotometer ELX800UV from BioTEK instruments. The detection limit was estimated at $0.04 \mu \mathrm{g} \mathrm{L}^{-1}$ and the range between 0.04 and $2.5 \mu \mathrm{g} \mathrm{L}^{-1}$. Therefore, the samples had to be diluted with ultrapure water before analysis. Concentrations of both intracellular and extracellular forms are reported per cell.

\section{Statistical analysis}

Results are expressed as mean +/- standard deviations. One-way ANOVA for non equal variance followed by a post-hoc Tukey test was performed for all statistical tests during each of the growth phases with significance threshold set at 0.05 .

\section{RESULTS}

A high correlation $\left(\mathrm{R}^{2}=0.92 ; \mathrm{n}=45\right.$ not shown) was found between optical density at 750 $\mathrm{nm}$ and cell numbers estimated by counting on an optical microscope. This relation, which was similar for the three light intensities, was used to infer the evolution of biomass. Growth rates and length of growth phases varied with light intensities. Growth rates were significantly different $(\mathrm{p}<0.05$, Tukey test) between each light intensity with the highest value of $0.136 \pm$

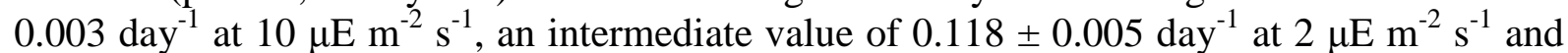
the lowest value of $0.100 \pm 0.003$ day $^{-1}$ at $20 \mu \mathrm{E} \mathrm{m}^{-2} \mathrm{~s}^{-1}$. Very low variance was observed between the triplicates for each modality. While the latent phase length (4 days) was similar for all light intensities, the exponential growth phase was longer at $10 \mu \mathrm{E} \mathrm{m}^{-2} \mathrm{~s}^{-1}$ (40 days) and was equal to 30 days at the other two light intensities.

At the beginning of the experiment, during the latent phase, there was no significant difference in the CYN content (either forms) between the replicates cultured at different light intensities ( $p>0.05$, Tukey test). We observed an intracellular CYN concentration varying between 1.9 and $2.6 \mathrm{fg}$ cell $^{-1}$ and an extracellular CYN concentration varying between 9.3 and $12.4 \mathrm{fg} \mathrm{cell}^{-1}$ with over $80 \%$ as extracellular CYN (Fig.1). 

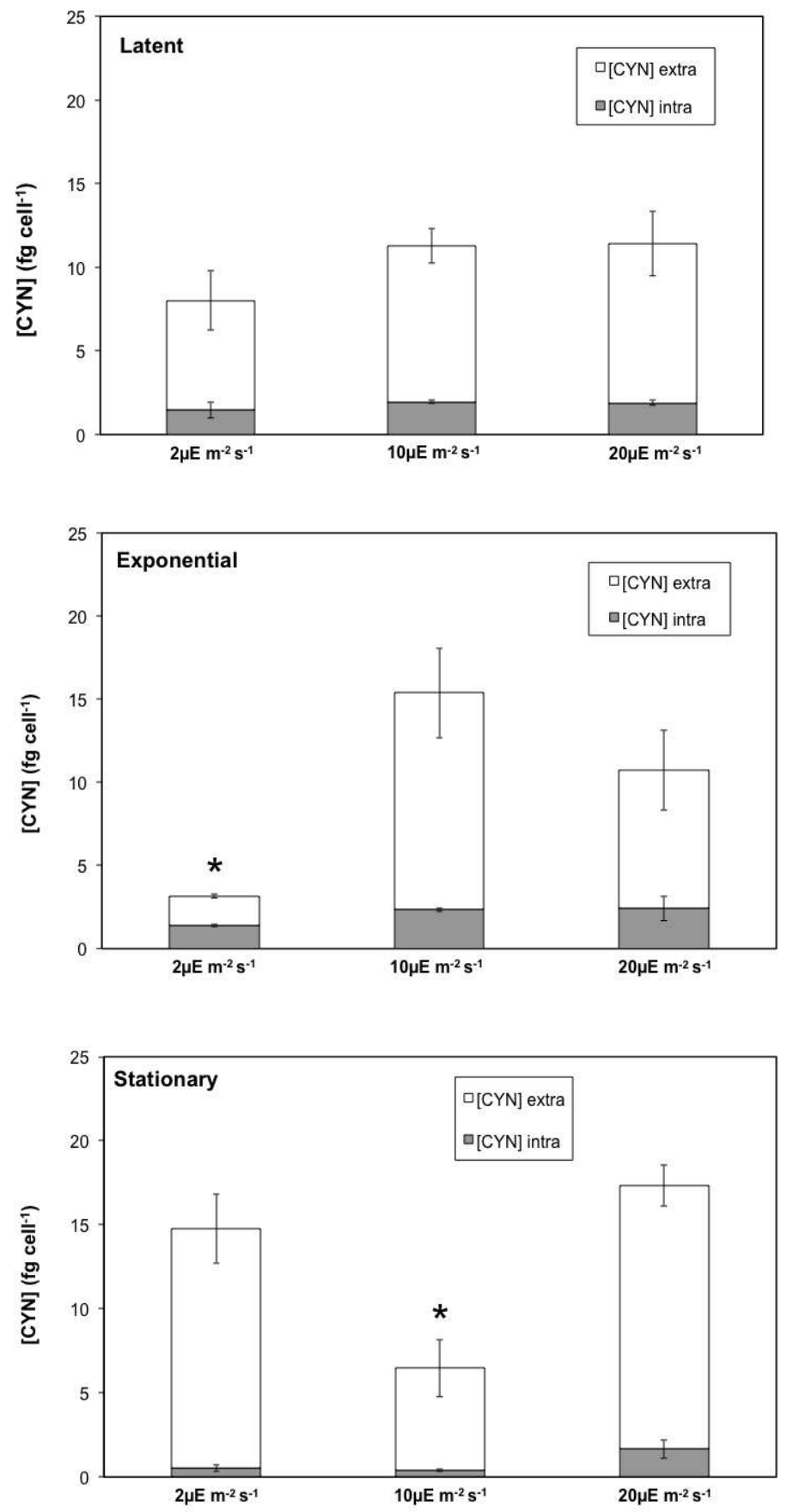

Fig. 1 : Intracellular and extracellular CYN concentrations (fg cell $\left.{ }^{-1}\right)$ as a function of light during the latent, exponential and stationary growth phase

During the exponential growth phase the highest proportion of the toxin was again in extracellular form at all light levels varying between $56 \%$ at $2 \mu \mathrm{E} \mathrm{m}^{-2} \mathrm{~s}^{-1}$ to $84 \%$ at $10 \mu \mathrm{E} \mathrm{m}^{-2}$ $\mathrm{s}^{-1}$. CYN concentrations were significantly lower ( $\mathrm{p}<0,05$, Tukey test) at $2 \mu \mathrm{E} \mathrm{m}^{-2} \mathrm{~s}^{-1}$ for both forms with values of $1.40 \pm 0.04 \mathrm{fg} \mathrm{cell}^{-1}$ as intracellular and $1.77 \pm 0.06 \mathrm{fg} \mathrm{cell}^{-1}$ as extracellular form compared to the other light levels (Fig.1). During the exponential growth phase, we therefore observed a significantly lower $(\mathrm{p}<0.05$, Tukey test) total CYN content at $2 \mu \mathrm{E} \mathrm{m}^{-2} \mathrm{~s}^{-1}$ compared to the other two light levels.

During the stationary phase, again most of the toxin was in extracellular form with proportions varying with light levels between $89 \%$ at $10 \mu \mathrm{E} \mathrm{m}^{-2} \mathrm{~s}^{-1}$ and $96 \%$ at $2 \mu \mathrm{E} \mathrm{m} \mathrm{m}^{-2} \mathrm{~s}^{-1}$. 
Both intracellular and extracellular CYN concentrations varied with light intensity and were significantly higher ( $\mathrm{p}<0.05$, Tukey test) at $20 \mu \mathrm{E} \mathrm{m}^{-2} \mathrm{~s}^{-1}$ than at the other light levels. Total CYN content was maximal at $20 \mu \mathrm{E} \mathrm{m}^{-2} \mathrm{~s}^{-1}$ during the stationary phase with concentrations per cell of $19.6 \pm 2.4 \mathrm{fg}$ cell $^{-1}$ (Fig.1). For a typical biomass observed in the field of $10^{5}$ cells $\mathrm{mL}^{-1}$, these values would be equivalent to $2 \mu \mathrm{g} \mathrm{L}^{-1}$, a value twice the recommended drinking water guideline of $1 \mu \mathrm{g} \mathrm{L}^{-1}$ (Humpage and Falconer 2003).

Although the maximum total CYN content during the exponential growth phase coincided with the maximum growth rate (at $10 \mu \mathrm{E} \mathrm{m} \mathrm{m}^{-2} \mathrm{~s}^{-1}$ ), the lowest CYN contents at $2 \mu \mathrm{E} \mathrm{m} \mathrm{m}^{-2} \mathrm{~s}^{-1}$ were not associated with the lowest growth rates. Therefore we did not observe a consistent relationship between growth rate and either intracellular or total CYN content (Fig. 2).
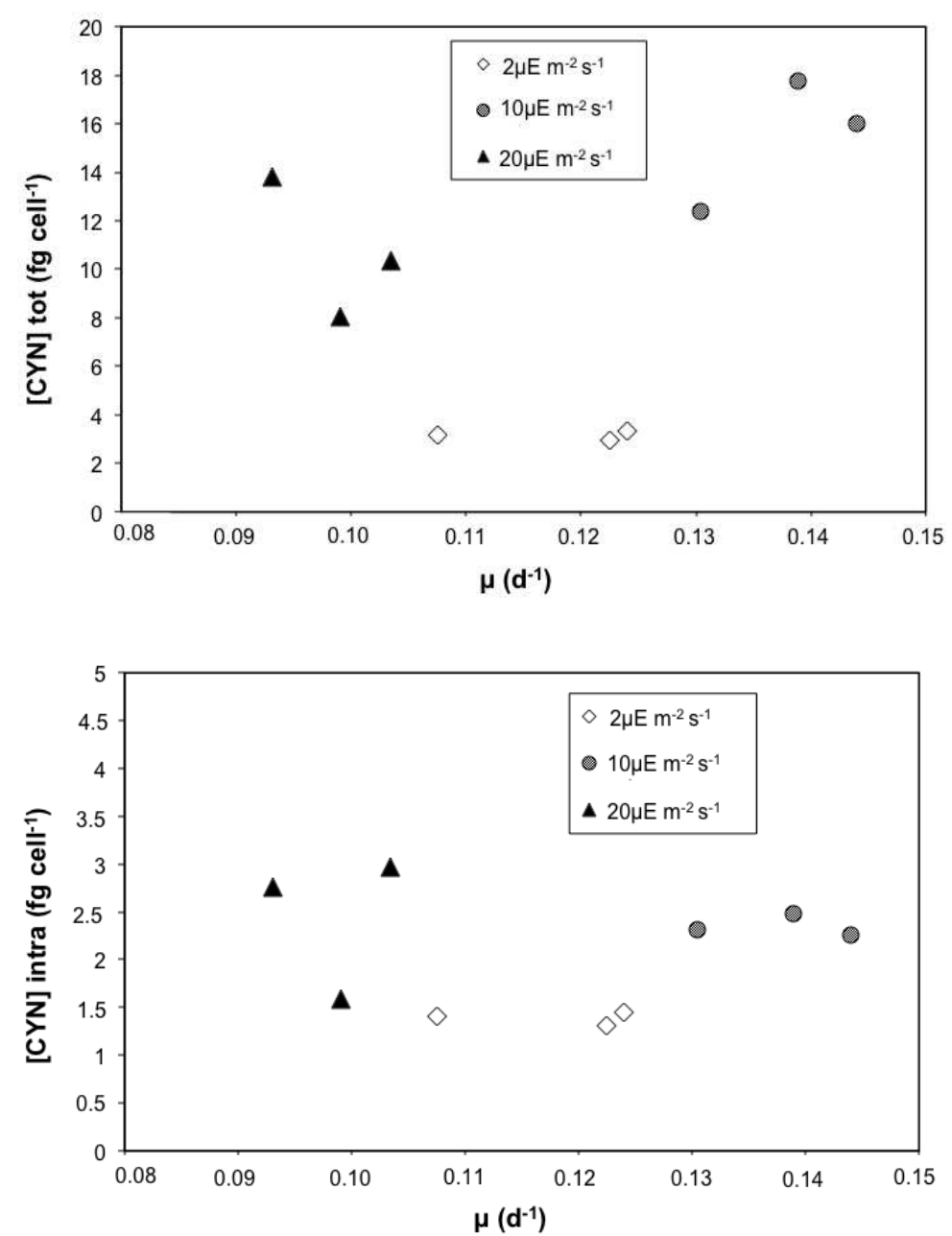

Fig. 2 : Total and intracellular CYN concentrations (fg cell $\left.{ }^{-1}\right)$ versus growth rates $\left(\mathrm{d}^{-1}\right)$ during the exponential phase at different light intensities.

\section{DISCUSSION}

In this study, we showed a dominance of extracellular CYN content regardless of the growth phase and the light level for the benthic species Oscillatoria sp. Dominance of extracellular CYN (62\%) for the same strain Oscillatoria sp. PCC 6506 was also observed by Mazmouz et al. (2010) after 11 days of growth at $20^{\circ} \mathrm{C}$ and in a nutrient rich medium and a constant light level of $15 \mu \mathrm{E} \mathrm{m}^{-2} \mathrm{~s}^{-1}$, which was likely to correspond to the exponential phase. The results presented here on the CYN content for a benthic species being mostly extracellular are in accordance with results for planktonic species, although very few studies have reported on 
CYN release and presented extracellular concentrations values. Dominance of extracellular CYN was observed in the field in lakes dominated by the Aphanizomenon genus (Wiedner et al. 2008). In laboratory experiments, extracellular proportions varied with abiotic factors and species. Cires et al. (2011) reported over $60 \%$ of extracellular CYN at extreme temperature for Aphanizomenon ovalisporum and Preußel et al. (2009) reported extracellular CYN concentration up to $58 \%$ under stress conditions, suggesting that the release of CYN was stress induced. Increases in extracellular concentrations under stress conditions have also been reported for microcystin (MC) producers associated with high light (Wiedner et al. 2003) or grazing pressure (Zhang et al. 2010). Nevertheless, for MC producers, the majority of the toxin is in intracellular form except during cell lysis.

Although the CYN concentration was found to be mostly in extracellular form, we observed a growth phase effect. Our results suggest relatively higher intracellular CYN content during the exponential growth phase and higher extracellular CYN content during the stationary phase. Very few studies have examined the CYN accumulation and release during the stationary phase (Hawkins et al. 2001; Dyble et al. 2006). However, they all report an increase of extracellular form during the stationary phase in accord with an increase observed in the field at the end of the bloom in a seasonal dynamics (Wiedner et al. 2008). This characteristic seems therefore to be common to all CYN producers studied so far.

We observed also a light effect on CYN accumulation and release. A statistically significant lower concentration of extracellular CYN was observed at the intermediate light level during the stationary phase. Due to the higher biomass reached this result can be in part due to a dilution effect, which occurs when the growth rate is higher than the toxin production rate. Observed higher extracellular CYN concentration at lower and higher light levels are consistent with a more limiting environment associated with stressed conditions. Indeed, stress related release of extracellular CYN has been suggested under $\mathrm{N}$ limitation (Preußel et al. 2009). We also observed a light intensity effect with lower CYN content of both intracellular and extracellular form during the exponential phase at low light leading to a lower total CYN content. This result is similar to that of planktonic species, which tend to show higher accumulation of intracellular CYN concentration at higher light levels.

We did not observe a monotonic relationship between growth rate and either intracellular or total CYN concentration. This result is similar to published studies on other CYN producers, which do not show a consistent relationship between CYN concentration and $\mu$. Indeed high CYN concentrations have been measured at high light intensities in Cylindrospermopsis raciborskii when growth rates were not at their maximum (Dyble et al. 2006). Similarly, Saker and Neilan (2001) found high intracellular CYN concentrations in low nitrogen Cylindrospermopsis raciborskii cultures while growth rates were suboptimal. There were no correlations between growth rates associated with variations of both temperature and light and either intracellular or total CYN contents in studies on Aphanizomenon flos aquae (Preußel et al. 2009; Cires et al. 2011). This lack of relationship between growth rate and CYN content contrasts with MC producers which often show a strong linear relationship between intracellular MC and $\mu$ (Orr and Jones 1998; Briand et al. 2012) suggesting different functional roles for these toxins.

In summary, we found that a benthic species produced predominantly extracellular CYN with an increase during the stationary phase in accord with planktonic CYN producers possibly indicating a stress response. No correlation was found between growth rate and CYN content again in a similar way to planktonic CYN producers' response. Hence the results presented in 
this study, although preliminary, suggest many similarities with planktonic CYN producers. Further studies should include testing intra species variability amongst Oscillatoria as well as other benthic species before generalization can be attempted. As the CYN toxin is predominantly present in an extracellular form in the environment, its presence is particularly problematic in water bodies used for drinking water purposes or recreational activities. In view of major ecological implications from benthic CYN producers, which include grazing by benthic organisms bioaccumulating in the food chain, it is somewhat surprising that benthic cyanobacteria have received so little attention.

\section{Acknowledgements}

This work was financed by the National Agency for Security of Environment and Health (ANSES) through the TOXCYN project. The experiment was run in the phytotronic chambers of the experimental facilities ECOLEX of ECOBIO.

\section{REFERENCES}

Bar-Yosef Y, Sukenik A, Hadas O, Viner-Mozzini Y, Kaplan A (2010) Enslavement in the water body by toxic Aphanizomenon ovalisporum, inducing alkaline phosphatase in phytoplanktons. Curr Biol 20:1557-1561

Brient L, Lengronne M, Bormans M, Fastner J. 2008. First occurrence of cylindrospermopsin in freshwater in France. Environ Toxicol 24(4):415-420

Briand E, Bormans M, Quiblier C, Salençon MJ, Humbert JF (2012) Evidence of the cost of the production of Microcystins by Microcystis aeruginosa under differing light and nitrate environmental conditions. PlosOne 7(1):e29981

Chiswell RK, Shaw GR, Eaglesham G, Smith MJ, Norris RL, Seawright AA, Moore MR (1999) Stability of cylindrospermopsin, the toxin from the cyanobacterium, Cylindrospermopsis raciborskii : Effect of $\mathrm{pH}$, temperature and sunlight on decomposition. Environ Toxicol 14:155-161

Cires S, Wörmer L, Timon J, Wiedner C, Quesada A (2011) Cylindrospermopsin production and release by the potentially invasive cyanobacterium Aphanizomenon ovalisporum under temperature and light gradients. Harmful Algae 10(6):668-675

Codd GA, Morrison LF, Metcalf JS (2005) Cyanobacterial toxins: risk management for health protection. Toxicol Appl Pharmacol 203:264-272

Dyble J, Tester PA, Litaker RW (2006) Effects of light intensity on cylindrospermopsin production in the cyanobacterial HAB species Cylindrospermopsis raciborskii. Afr J Mar Sci 28:309-312

Hawkins PR, Putt E, Falconer I, Humpage A (2001) Phenotypical variation in a toxic strain of the phytoplankter, Cylindrospermopsis raciborskii (Nostocales, Cyanophyceae) during batch culture. Environ Toxicol 16(6):480-487

Humpage AR and Falconer IR (2003) Oral toxicity of the cyanobacterial toxin cylindrospermopsin in male Swiss albino mice: Determination of no observed adverse effect level for deriving a drinking water guideline value. Environ Toxicol 18(2):94-103

Kinnear S (2010) Cylindrospermopsin : A decade of progress on bioaccumulation research. Mar Drugs 8:542-564 
Mazmouz R, Chapuis-Hugon F, Mann S, Pichon V, Méjean A, Ploux O (2010) Biosynthesis of cylindrospermopsin and 7-epicylindrospermopsin in Oscillatoria PCC 6506 ; Identification of the gene cluster and toxin analysis. Appl Environ Microbiol 76(15):4943-4949

Orr P, Jones G (1998) Relationship between microcystin production and cell division rates in nitrogenlimited Microcystis aeruginosa cultures. Limnol Oceanogr 43(7):1604-1614

Preußel K, Wessel G, Fastner J, Chorus I (2009) Response of cylindrospermopsin production and release in Aphanizomenon flos-aquae (cyanobacteria) to varying light and temperature conditions. Harmful Algae 8:645-650

Rücker J, Stüken A, Nixdorf B, Fastner J, Chorus I, Wiedner C (2007) Concentrations of particulate and dissolved cylindrospermopsin $(\mathrm{CYN})$ in 21 Aphanizomenon dominated lakes of North East Germany. Toxicon 50:800-809

Saker ML, Griffith DJ (2000) Effects of temperature on growth and cylindrospermopsin content of seven isolates of $C$. raciborskii (Nostocales, Cyanophyceae) from water bodies in northern Australia. Phycologia 39:349-354

Saker ML, Neilan BA (2001) Varied diazotrophies, morphologies, and toxicities of genetically similar isolates of Cylindrospermopsis raciborskii (Nostocales, Cyanophyceae) from Northern Australia. Appl Environ Microbiol 67(4):1839-1845

Seifert M, McGregor G, Eaglesham G, Wickamasinghe W, Shaw G (2007) First evidence for the production of cylindrospermopsin and deoxy-cylyndrospermopsin by the freshwater benthic cyanobacterium, Lyngbia wollei (Fallow ex Gomont) Spezialeand Dick. Harmful Algae 6:73-80

Sinha R, Pearson LA, Davis TW, Burford MA, Orr PT, Neilan BA (2012) Increased incidence of Cylindrospermopsis raciborskii in temperate zones - Is climate change responsible? Water Res 46:1408-1419

Welker M, Bickel H, Fastner J (2002) HPLC-PDA detection of cylindrospermopsin - opportunities and limits. Water Res 36:4659-4663

Wiedner C, Visser PM, Fastner J, Metcalf JS, Codd GA, Mur LR. 2003. Effects of light on the microcystin content of Microcystis strain PCC 7806. Applied and Environ Microb 69:1475-1481

Wiedner C, Rücker J, Fastner J, Chorus I, Nixdorf B (2008) Seasonal dynamics of cylindrospermopsin and cyanobacteria in two German lakes. Toxicon 52:677-686

Wörmer L, Cires S, Carrasco D, Quesada A (2008) Cylindrospermopsin is not degraded by cooccurring natural bacterial communities during a 40-day study. Harmful Algae 7:206-213

Wörmer L, Huerta-Fontela M, Cires S, Carrasco D, Quesada A (2010) Natural photodegradation of the cyanobacterial toxins microcystin and cylindrospermopsin. Environ Sci Technol 44(8):3002-3007

Zhang X, Hu H, Men Y, Christoffersen KS. 2010. The effect of Poterioochromonas abundance on production of intra and extracellular microcystin-LR concentration. Hydrobiologia 652:237-246 